\title{
Portrayal of Underprivileged Children: Problem of Child Labour in Lost Spring: Stories of Lost Childhood by Anees Jung
}

\author{
Neeharika Singh Lodhi
}

Ph.D. Scholar, Department of Modern Indian Languages and Literary Studies, University of Delhi, New Delhi

Received: 22 Sept 2020; Received in revised form: 17 Nov 2020; Accepted: 25 Nov 2020; Available online: 1 Dec 2020

(C)2020 The Author(s). Published by Infogain Publication. This is an open access article under the CC BY license

(https://creativecommons.org/licenses/by/4.0/).

\begin{abstract}
Children have been at the receiving end of physical and mental abuse, discrimination and harassment which has ill-effects on their growth. Despite the establishment and enforcement of various national and international laws which protect their rights, they face these challenges. Endless hurdles in their lives, from lack of education to their exploitation as a human resource, are complexly entangled with the issue of poverty they face. This paper attempts to explore Anees Jung's "Lost Spring: Stories of Lost Childhood" to understand the problems that children face, whose lives are entangled with structures of poverty, gender, caste etc. The paper also attempts to discuss the solutions to these problems as given by Jung.
\end{abstract}

Keywords - child labour, child rights, discrimination, harassment, human rights, mental abuse, physical abuse.

\section{INTRODUCTION}

"Human Rights are inherent and unalienable rights which are due to an individual by virtue of his/ her being a human. These rights are necessary to ensure the dignity of every person as a human being irrespective of one's race, religion, nationality, language, sex or any other factor... These rights have been translated into legal rights, established according to the law-creating processes of societies, both national and international" (Yasin and Upadhyay, 1).

Human Rights are inherent rights for all humans which have been legally enforced all across the world in different forms. Despite this human life and human dignity have been disregarded throughout history and continue to be disregarded today. Denial of dignity continues on various grounds and extends even to children, as in our society, some children have to live their childhood as labourers. Working as labourers, children are deprived of their childhood, their dignity, growth, and physical and mental well-being. According to the Census of 2011, there are 4.35 million working children between the age of 5-14 in India.

Anees Jung is a famous writer, who has written on the issue of human rights violations including that of children in her works. This paper attempts to explore and evaluate the portrayal of the plight of underprivileged children in Jung's Lost Spring: Stories of Lost Childhood.

\section{CHILD RIGHTS AND OTHER INITIATIVES}

According to the Convention on the Rights of the Child by UNICEF, which was ratified by India in 1989, a child is anyone under the age of 18 years. According to the Convention, a child has the right to live and has right against discrimination. Article 24 of the Convention states that "Children have the right to the best health care possible, clean water to drink, healthy food and a clean and safe environment to live in". Article 27 gives them "the right to food, clothing and a safe place to live so they can develop in the best possible way." The Convention also grants the right to an education to every child. India is also obliged to follow the International Labour Organizations (ILO) Convention No. 182 which prohibits children from engaging in any hazardous work which is likely to jeopardize their physical, mental or moral health. It aims at absolute elimination of the worst forms of child labour for kids below 18 years.

Along with these international laws, the Constitution of India (1950) also protects rights of children 
and prohibits their exploitation. Article 21(A) of the Constitution provides free and compulsory education for all children in the age group of 6-14 yrs. Article 24 also explicitly forbids the employment of children below the age of fourteen years in unsafe factories which may cause them physical and mental harm. Apart from the Constitution, there are many specific laws that regulate the employment of children in various arenas. The Child Labour Amendment (Prohibition and Regulation) Act, 2016 is one such Act. It regulates the employment of children and prohibits children below the age of 14 to work except in a family business or as artists.

Many non-profit organisations run by activists also closely work with the government to ensure the mental and physical well-being of all children. They assist government in making laws, catching the culprits who do not adhere to the laws, and spreading awareness among masses. Not only social activists but literary figures too have participated in this cause across the globe, since centuries. Writers like William Blake, Charles Dickens, Alice Walker, etc., including Indian writers in English language like Kashmira Sheth, Asha Nehemiah and Anees Jung have dealt with this issue.

\section{CHILD LABOUR AND EXPLOITATION OF CHILDREN IN LOST SPRING: STORIES OF LOST CHILDHOOD}

The practice of child labour prevails in India despite the many initiatives and national and international laws that India adheres to. Child labour is exploitative which spoils childhood and deprives children of basic facilities that are necessary to nurture them naturally into a mature human being. The practice of child labour, despite being seen as a kind of exploitation, continues to exist.

Anees Jung's Lost Spring: Stories of Lost Childhood is a collection of short stories in which Jung interviews and describes her encounter in different cities across India, with children that have worked or are working because of various reasons, and also with other people related to them. Their stories highlight the violation of children's right, discussed above, on multiple levels.

There are numerous factors that lead a child into ordeal of child labour. Poverty is the most significant one. Generally, for poor households that have to earn their livelihood on a day-to-day basis, money earned by working children is always a welcome addition. In other cases, like in petty family businesses, children assist their parents to earn more money.
In all of Jung's narratives, we find poverty as the major cause of child labour. Lakshmi pollinates flowers in cotton fields for which she only gets ten rupees. Raju, only 10 years old, works at a roadside Dhaba for sixteen hours a day. Munni has come to the city looking for work in order to support her family. And there are a lot many children showcased in the stories that have spent their youth working in factories making fireworks, bangles, locks, in farms, as domestic help, at construction sites, mending bicycles, bearing heavy loads. Sometimes, they are exploited to the extent that they become sexual objects for rich and powerful. They are victims of physical and mental abuse, yet they work in order to earn at least two meals a day.

In India, as shown by Jung, the state of poverty is generally experienced by people of low castes, landless villagers migrating to cities, refugees and illegal immigrants especially from Bangladesh. In one of the stories, Jung tells us about the life of Jagannath to show as to why people of low caste move to cities. After moving to Hyderabad, he says, "in the village, we were considered children of Dheedwada, the untouchables. We could not sit with others." But in the cities, he observes, people sit and "drink together in toddy shops." In another story, Jung hints towards misconception among poor villagers that cities have a panacea to all their problems and shows the migration of Nayak from village to city in order to make more money to sustain his family. Nayak in this story says that he saw one of his neighbours who returned from the city wearing gold rings and therefore decided to come to the city only to realize years later that those rings were fake. Others like families of Saheb, a rag-picker, are refugees from Dhaka that are settled in slums of Seemapuri in Delhi.

Poverty makes childhood miserable. In almost all the scenes in cities to which Jung takes us to, we are told that there is no place for children to play and grow. "The city has grown, the families have multiplied... There are no playgrounds." Also, the surroundings in which they live are completely unhealthy. The surroundings are "mud paths choked with garbage swarming with buzzing black flies..."

Jung points out that poverty has made man insensitive. She says, in fact "only a fine line seems to separate the humans from the animals" in such surroundings. Priorities have been shifted. Instead of loving or caring, mothers shriek and push children around. She notes an incident where flies settle on the face of a sleeping baby but when the mother is told to cover his face, she almost suffocates him to death. Thus, the environment in which they grow is not the ideal one for a child.

Poverty also pushes towards the wrong prioritization of utilization of available resources, which in 
turn leads to less education or no education. People living in slums or rural areas do not have access to basic amenities, let apart education, which even if available is, either not affordable or of poor quality. Likewise, we see in some of the stories some teachers are neither regular nor punctual. In cases, where education is not available for children, they are destined to work for money or food and shelter. Also, many of the uneducated parents cannot foresee the importance of children's education, they, rather see it is as a waste of time and money and instead engage them in work for some earning.

It is seen that children are engaged in difficult and risky jobs which often cause physical and mental damage. Generally, at such workplaces, children get vilified, harassed, or experience violence and abuse. For example, one such child Idrees loses his memory because of the trauma he faced in the carpet factory. Similarly, Zafar while working in the lock factory gets his two fingers chopped off. Also, there are children engaged in fireworks and glass factories who will not live for long. Girls like Rani are exposed to harmful chemicals while working in cotton fields.

Jung for her stories interviews many employers who justify hiring young children as "only children can do certain jobs...only small hands can fit levers, only small hands can knot carpets". Some others say that "they were cheap, because they work longer hours without complaining, and because they had no wife or family to go home to."

Employers prefer to hire children because they are cheaper than their adult counterparts, they can get rid of easily if not required and they are also a submissive, obedient work-force that will not likely organize itself for protection or support. Sometimes, children receive no payment and only get food and a place to sleep. Children, in such an unorganized work setup, get no compensation if they get injured or become ill, and they have no protection against injustice or ill-treatment.

Girl child labour face even more problems. They are married at an early age because parents can't afford huge dowries, the younger the girl the lesser the dowry. Girls, who could not get married are engaged in work, like Munni who reached the city to earn money as a housemaid, to support her family. Jung tells us that they are fooled into making money in big cities by "uncles", who bring them to the cities and sell them here. Girls like her generally end up in flash trade.

Situations are no different even for boys. In one of the stories situated in Goa, Georgina's son is being kept by a Danish man, who has financed her shack and even had taken the boy to Denmark.

\section{DISCUSSING THE SOLUTIONS GIVEN BY JUNG}

Jung, in her collection, addresses the issue of education as a remedy for this problem. She highlights the power of education and depicts the lives of many people that have understood the importance of child education. There are many children who consider education as the only vehicle to lead to a better life. Like Deepak dreams to become a pilot, Mukesh a mechanic, Puran a teacher, and Mahendar dreams to have his own shop. Jung recognizes their dreams and shows something like this is possible. She cites individuals, organizations and villages that are working towards the goal of a better life for children.

Parents too are changing now, as Jung notices, parents coming to the school with their child saying "I want her to live here and learn". Indu Rao, a rag-picker in Pune who sent her daughter to school and even mobilized other rag picker women arguing for improvement of working conditions including crèches and child care centres and provision for social security. On the other hand, one such child Prema herself, in a small village on the coast of Arabian sea, along with many girls formed Children's Panchayat and held a survey of 12,000 households enquiring about children's demand like quality education, easy access to food and water; and presented them to the adult panchayat. Parents have also followed what Prema started which has changed the mindset of the entire village. Jung records "This village now is a child-labour-free village."

Jung mentions organization, like 'Concerned for Working Children (CWC)' has created 'Namma Bhoomi', a village that takes care of all the needs of the children. Here children sat with architects and discussed their needs according to which the village was built.

Individuals, like Sharat Babu, helped to develop basti schools. Jayaram Sharma in his village opened up a school and asked only for a fistful of grain for teaching a child. The fathers refused, saying that they are poor but mothers came forward and helped their children. This led to setting up of 32 schools called 'Mutthi Bhar Anaaj Ke School'.

Jung also shows some contrasting examples like that of Nayak, who himself once was a child labourer in restaurants, now owns a chain of restaurants and hotels. However, despite his own experience of hardships of child labour, he has employed children as workers and justifies this by saying that if he doesn't give them work, "he will add to their family burden". Though, Jung doesn't seem to buy Nayak's justification. According to her, unless it is addressed by each one of us, the government, the NGOs, 
industries, the families who send their children to work, the society which employs children, uses them pretending that it is an act of charity, that by doing so it is helping the child and his family, child labour will not end.

Jung's work is a non-fictional one, giving true accounts in simple, engaging and lucid narration. It is commendable that she took pains to go and talk to concerned persons in real situations. She travelled across India and visited many cities and villages to interact with these children. She went from Delhi to Hyderabad, from Rajasthan to Udipi and many other places. She did not write about this issue on the basis of presuppositions sitting in her comfort, but went to slums, visited schools, factories, to rehabilitation homes. She not only interacted with children but with others like parents, teachers, and activists as well, who affect the lives of these children. This helped her to come to a better understanding of the issue resulting in a better presentation before readers.

It seems Jung efficiently reads the mental state of children and their circumstances. However, Mishty Varma, in Hindustan Times, observes that "I feel that Ms. Jung's solution - of formal schooling for children - was too simple for the situations of these children." The problem in Jung's work is that it appears as if she believes that education alone can eradicate child labour. Yes, education is one of the solutions, but that's not all. Though she highlights that poverty is the reason behind most of these working children, she does not provide a solution for dealing with this. Jung may have suggested some sort of remedy so that the children may be spared from the burden of earning for their families.

A practical solution for eradicating poverty can be that the government should provide students with a monetary incentive. Children add about 10-20 rupees a day to the earnings of their families. If the government could provide these children who come to school with this money, they might get a chance to be properly educated along with sustaining their families. Because as shown in her work, it is not that all parents are unwilling to educate their children, but it is poverty that stops them.

Alongside this, however, the government must enforce law and order against Child Labour by keeping a check on kidnapping, human trafficking, etc. Also, people need to take a few steps on their part. They have to stop exploiting others especially young children for their comfort. People also need to be watchful; they should not turn a blind eye to a working child. Moreover, one must always try to facilitate the poor adults, provide them with opportunities to work. In this way, we might achieve a child-labour-free world.

\section{CONCLUSION}

In view of the above, we can safely conclude that Jung has successfully portrayed the problem of child labour. She has managed to show us real cases in real situations, providing an understanding of the holistic view of child labour problem. She advocates for education for all children as their right and tells us soul-stirring stories where people are fighting for children's rights and also as to how education has transformed the lives of people. It would have been even more impressive had she given a more effective solution for the complex problem she discussed.

\section{REFERENCES}

[1] "Census Data on Child Labour". Ministry of Labour and Employment. Web. 16 November 2020. https://labour.gov.in/childlabour/census-data-child-labour

[2] "Convention on the Rights of the Child". United Nations Human Rights. Web. 10 November 2020. https://www.ohchr.org/en/professionalinterest/pages/crc.as $\mathrm{px}$

[3] Jung, Anees. Lost Spring: Stories of Lost Childhood. New Delhi: Penguin Books India, 2005. Print.

[4] "The Child Labour (Prohibition and Regulation) Amendment Act, 2016". Ministry of Labour and Employment. Web. 16 November 2020. https://labour.gov.in/whatsnew/child-labour-prohibitionand-regulation-amendment-act-2016

[5] "The Constitution of India". National Portal of India. Web. $30 \quad$ September 2020. https://www.india.gov.in/sites/upload_files/npi/files/coi_pa rt_full.pdf

[6] Varma, Mishty. "Jung exposes national shame". Hindustan Times 17 Nov 2005. Web. 11 Nov 2020. https://www.hindustantimes.com/books/jung-exposesnational-shame/story-A3Bk3dW1nKnHlJ01rCntMK.html

[7] "Worst Forms of Child Labour Convention, 1999 (No. 182)". International Labour Organization. Web. 14 November 2020. https://www.ilo.org/dyn/normlex/en/f?p=NORMLEXPUB: 12100:0::NO::P12100_ILO_CODE:C182

[8] Yasin, Adil-ul, Archana Upadhyay. Human Rights. New Delhi: Akansha Publishing House, 2004. Print. 